\title{
PHYSICOCHEMICAL CHARACTERISTICS OF PURPLE LETTUCE HARVESTED AT DIFFERENT AGES ${ }^{1}$
}

\author{
LORENA DE OLIVEIRA MOURA ${ }^{2 *}$; LANAMAR DE ALMEIDA CARLOS ${ }^{3}$; KÊNIA GRASIELLE DE OLIVEIRA ${ }^{2}$; \\ LUMA MOREIRA MARTINS ${ }^{2}$; ERNANI CLARETE DA SILVA ${ }^{2}$
}

\begin{abstract}
Lettuce is one of the most produced and consumed leafy vegetables in Brazil. It is harvested when the plant reaches full vegetative growth and the leaves are still tender and there are no signs of bolting. The plant is unsuitable for commercialization after this period, thus, a food that is rich in vitamins, minerals and bioactive compounds such as carotenoid is lost. Therefore, the objective of this work was to assess the purple lettuce quality based on physical-chemical characteristics, in three different ages. The experiment was conducted in an urban community garden in Sete Lagoas MG, Brazil. A completely randomized experimental design was used with three replications. The treatments consisted of three development stages (20, 30 and 40 days after transplanting - DAT). The treatment with 40 DAT presented total carotenoids concentration and soluble solids content significantly higher, lower $\mathrm{pH}$, and darker lettuce, with lower values of the parameter $\mathrm{b}^{*}$ (increase in yellow color), and higher values of the parameter a* (increase in red color), compared to the first two treatments. The titratable acidity was statistically equal for the three evaluation periods. Considering the high concentration of carotenoids found at 40 DAT, the harvest can take place at this age.
\end{abstract}

Keywords: Development stages. Lactuca sativa. Harvest time.

\section{CARACTERÍSTICAS FÍSICO-QUÍMICAS DE ALFACE ROXA COLHIDAS EM DIFERENTES IDADES}

\begin{abstract}
RESUMO - A alface é uma das hortaliças folhosas mais produzidas e consumidas no Brasil. A colheita ocorre no período em que a planta atinge o crescimento vegetativo máximo, as folhas ainda estão tenras e sem indícios de pendoamento. Após este período, a planta é considerada inadequada para a comercialização, perdendo-se um alimento rico em vitaminas, sais minerais e composto bioativos, como os carotenóides. Desta forma, este trabalho teve o objetivo de avaliar a qualidade com base em mudanças físico-químicas em uma cultivar de alface roxa durante três idades diferentes. $\mathrm{O}$ trabalho foi desenvolvido em uma horta comunitária urbana no município de Sete Lagoas -MG. O delineamento experimental foi inteiramente ao acaso com três repetições sendo os tratamentos os três estádios de desenvolvimento (20, 30 e 40 dias após transplantio - DAT). Aos 40 DAT, a concentração de carotenóides totais e o teor de sólidos solúveis totais foram significativamente superiores, o pH foi menor; e a alface se tornou mais escura, apresentando menores valores do parâmetro $b^{*}$ (incremento da cor amarela) e maiores valores do parâmetro a* (incremento da coloração vermelha), diferindo significativamente das duas primeiras colheitas. A acidez titulável foi igual estatisticamente nas três épocas de avaliação. Considerando o alto conteúdo de carotenóides observado aos 40 DAT, pode-se considerar a colheita nesta idade.
\end{abstract}

Palavras-chave: Estádios de desenvolvimento. Lactuca sativa. Ponto de colheita.

\footnotetext{
*Corresponding author

${ }^{1}$ Received for publication in 09/16/2014; accepted in 01/28/2016.

${ }^{2}$ Department of Agricultural Sciences, Universidade Federal de São João del-Rei, Sete Lagoas, MG, Brazil; lorena.om@hotmail.com, keniagrasi@yahoo.com.br, lumamartins31@yahoo.com.br, clarete@ufsj.edu.br.

${ }^{3}$ Department of Food Engineering, Universidade Federal de São João del-Rei, Sete Lagoas, MG, Brazil; lanamar@ufsj.edu.br.
} 


\section{INTRODUCTION}

Lettuce (Lactuca sativa L.) is one of the most produced and consumed leafy vegetables, because it is ease acquired and prepared, it is produced throughout the year and has low cost. World production of lettuce exceed 24 million $\mathrm{Mg}$ (FAO, 2012) and the estimated average daily consumption of lettuce in Brazil is 3.6 grams per capita (IBGE, 2011).

Lettuce is a rich source of vitamins $A$ and $E$, minerals, polyphenols and other bioactive compounds such as carotenoids (NICOLLE et al., 2004a, 2004b). Carotenoids have pro-vitamin A (HASKELL, 2013) and antioxidant activities, acting on intercellular communication and the immune system, presenting a significant role in preventing various diseases related to oxidative stress such as cancer and cardiovascular diseases, and in lowering cholesterol (HUANG, 1980; CARVALHO et al., 2006; LLORACH et al., 2008; MAIANI et al., 2009; ROCHA; REED, 2014). The main types of carotenoids found in lettuce are lutein, $\beta$-carotene, violaxanthin, neoxanthin and lactucaxanthin (NIIZU; RODRIGUEZ-AMAYA, 2005).

Compounds found in vegetables such as soluble sugars, organic acids and pigments are important components that may contribute to their flavor and nutritional value, indicating the quality of these products. However, their chemical composition may change under influence of various factors (XIAO et al., 2012) such as the cultivar, production system, development stage (MAUROMICALE; IERNA; MARCHESE, 2006; GENT, 2012), the environmental temperature (GUEVARAFIGUEROA et al., 2015), soil type (PINTO et al., 2014) and incident radiation (CALDWELL; BRITZ, 2006).

Physical, chemical and biochemical changes occur during the maturation process of lettuce plants, which influence the quality attributes of vegetables, increasing the concentration of sugar, pectin solubilization, pigment degradation, increase in concentration of phenolic and acid compounds, volatile production and variations in enzyme, vitamins and minerals contents (RODRIGUEZAMAYA; KIMURA; AMAYA-FARFAN, 2008; LUNA et al., 2013; BECKER et al., 2014).

The development of lettuce varies according to the cultivar and environmental conditions such as temperature (YURI et al., 2002; LUZ et al, 2009), therefore, the commercial harvest time should take place in the period in which they have the best flavor, appearance, texture, aroma and nutritional quality, which occur before its physiological maturity (HAMADA; TESTEZLAF, 1995; BENINNI et al., 2005). The process of flowering, (stem emission or bolting) begins at maturity, which makes the leaves milkier, bitter (FILGUEIRA, 2003; LUZ et al., 2009) and no longer marketed.
Researches on lettuce are mostly conducted regarding product quality analysis up to the commercial harvest time, and not to the final stages of development (FAVARO-TRINDADE et al., 2007; PÔRTO et al., 2012; RICARDO et al., 2014; PINTO et al., 2014). Therefore, additional studies assessing the chemical composition of vegetables until the end of their cycle are needed, in order to establish the limit time for the harvest, and offer consumers more than products with good appearance and taste, but also with better nutritional quality.

Therefore, the objective of this work was to evaluate the carotenoids concentration and the physicochemical characteristics of red lettuce in three different ages.

\section{MATERIAL AND METHODS}

The experiment was conducted in an urban community garden in Sete Lagoas, MG, Brazil $\left(19^{\circ}\right.$ $28^{\prime} \mathrm{S}, 44^{\circ} 15^{\prime} \mathrm{W}$ and $732 \mathrm{~m}$ of altitude), in May and June 2014, which had $1 \mathrm{~mm}$ of precipitation, minimum temperatures of $9^{\circ} \mathrm{C}$ and maximum of $31^{\circ} \mathrm{C}$ (INMET, 2014). According to the Köppen classification, the climate is Aw, typical of Savannah, with dry winter and average air temperature of the coldest month above $18^{\circ} \mathrm{C}$. The soil was classified as dystrophic typical Red Latosol.

A purple colored lettuce cultivar was grown under SAT production system (where mineral fertilizer is permitted, without pesticides), fertilized with an organic compost produced from manure and crop residues from the garden.

A completely randomized experimental design was used with three replications. The plots consisted of $1.20 \mathrm{~m}$ wide, $0.90 \mathrm{~m}$ long beds, with plants spaced $0.30 \times 0.30 \mathrm{~m}$ apart in four rows, totaling 12 plants. The two central plants were used for analysis. The treatments consisted of three evaluation periods at 20,30 and 40 days after transplanting (DAT) of the seedlings.

The seedlings were grown in 200-cell polystyrene trays for 25 days after sowing, and then transplanted to the final locations according to the experimental design. The plants were irrigated every day on mornings and afternoons.

The lettuces were harvested on mornings and refrigerated transported, within about 40 minutes, to the Science and Food Technology Laboratory (UFSJ - Sete Lagoas Campus), where they were washed and prepared for physical-chemical and carotenoid analysis. The evaluated characteristics were dry matter, $\mathrm{pH}$, total soluble solids, instrumental color, titratable acidity and total carotenoids.

Dry matter content evaluation was gravimetrically performed, according to the AOAC (2012) protocol, subjecting $2 \mathrm{~g}$ of plant material to $105^{\circ} \mathrm{C}$ until constant weight in a sterilization and drying oven. 
The $\mathrm{pH}$ was potentiometrically measured with a digital pH-meter $\left(\right.$ Tekna $^{\circledR}$ T-1000). The homogenized sample $(5 \mathrm{~g})$ were added to $10 \mathrm{~mL}$ of deionized water and the readings were performed by direct immersion of the electrode.

The total soluble solids were found by refractometry (AOAC, 2012) with a digital refractometer, (Reichert ${ }^{\circledR} r^{2}$ mini). Drops of macerated and filtered samples were placed on the refractometer prism, with direct reading in degrees Brix $\left({ }^{\circ} \mathrm{Bx}\right)$.

The instrumental color was found with a colorimeter (Konica Minolta ${ }^{\circledR}$ ), expressed by the parameters $L^{*}, a^{*}$ and $b^{*}$ of the CIELAB system, where $\mathrm{L}^{*}$ is the brightness variable, ranging from 0 (black) to +100 (white), and the coordinates chromaticity a* ranging from green $(-)$ to red $(+)$ and $\mathrm{b}^{*}$ ranging from blue $(-)$ to yellow $(+)$. Measurements were performed in triplicates within each repetition, with three readings performed in each sample at equidistant points on the adaxial part of the lettuce leaf, using then the average values.

The titratable acidity was found by titration (AOAC, 2012), using a $\mathrm{NaOH} 0,01 \mathrm{~N}$ as standard solution and phenolphthalein as indicator. The titratable acidity was expressed in grams of citric acid per $100 \mathrm{~g}$ of fresh sample.

The carotenoid was assessed following the methodology proposed by Rodriguez-Amaya, 2001. The extraction was performed by grinding $5 \mathrm{~g}$ of the sample in a mortar with acetone, vacuum filtering this mixture on a Buchner's funnel, followed by additions of acetone to complete decolorizing. The ketonic extract was separated by addition of petroleum ether and water. The total carotenoids were quantified after extraction by spectrophotometry at $450 \mathrm{~nm}$ in a spectrophotometer $\left(\right.$ FEMTO $\left.^{\circledR} 700 \mathrm{~S}\right)$.

The data were submitted to analysis of variance by the $\mathrm{F}$ test and means were compared by the Tukey test at 5\% probability using the statistical program Sisvar 5.3, according to Granato; Calado e Jarvis (2014).

\section{RESULTS AND DISCUSSION}

The variance analysis of the red lettuce data presented significant differences $(\mathrm{p} \leq 0.05)$, between the evaluated ages $(20,30$ and 40 DAT), for dry matter, $\mathrm{pH}$, total soluble solids (TSS), instrumental color $\left(\mathrm{L}^{*}, \mathrm{a}^{*}\right.$ and $\left.\mathrm{b}^{*}\right)$ and carotenoids. The dry matter content found was $5.26 \%$ (20 DAT), 5.08\% (30 DAT) and 6.95\% (40 DAT), indicating an increasing accumulation with the plant development. This accumulation pattern was also observed by Castoldi et al. (2009) in cauliflower plants.

The evaluation at 40 DAT presented significantly lower $\mathrm{pH}$ compared to the previous phases (Table 1). Arbos et al. (2010) found $\mathrm{pH}$ values ranging from 6.04 to 6.22 in five samples of lettuce at commercial harvest time. These values are consistent with those found in the present study at evaluations 20 and 30 DAT, confirming that the value found at $40 \mathrm{DAT}$, at bolting, is lower.

Table 1. Mean $\mathrm{pH}$, soluble solids content (SSC) $\left({ }^{\circ} \mathrm{Bx}\right)$, instrumental color $\left(\mathrm{L}^{*}, \mathrm{a}^{*}, \mathrm{~b}^{*}\right)$, titratable acidity $(\mathrm{g}$ of citric acid per $100 \mathrm{~g}$ of sample) and carotenoids $\left(\mathrm{mg} \mathrm{g}^{-1}\right)$ of red lettuce harvested at 20, 30 and 40 days after transplanting (DAT).

\begin{tabular}{cccccccc}
\hline Treatments & $\mathrm{pH}$ & $\mathrm{SSC}$ & $\mathrm{L}^{*}$ & $\mathrm{a}^{*}$ & $\mathrm{~b}^{*}$ & Titratable acidity & Carotenoids \\
\hline $20 \mathrm{DAT}$ & $6,283 \mathrm{a}$ & $2,567 \mathrm{~b}$ & $44,027 \mathrm{a}$ & $-10,323 \mathrm{a}$ & $24,709 \mathrm{a}$ & $0,059 \mathrm{a}$ & $62,055 \mathrm{~b}$ \\
$30 \mathrm{DAT}$ & $6,158 \mathrm{a}$ & $2,500 \mathrm{~b}$ & $44,619 \mathrm{a}$ & $-11,457 \mathrm{a}$ & $26,488 \mathrm{a}$ & $0,055 \mathrm{a}$ & $49,775 \mathrm{~b}$ \\
$40 \mathrm{DAT}$ & $5,967 \mathrm{~b}$ & $3,567 \mathrm{a}$ & $31,887 \mathrm{~b}$ & $2,536 \mathrm{~b}$ & $9,406 \mathrm{~b}$ & $0,074 \mathrm{a}$ & $128,098 \mathrm{a}$ \\
\hline CV $\%$ & 1,01 & 11,58 & 4,53 & 23,61 & 9,37 & 31,28 & 24,42 \\
\hline
\end{tabular}

Means followed by the same letter in the same column do not differ statistically at $5 \%$ probability by the Tukey test.

There was no significant difference in total soluble solids content in the first two evaluation periods (20 and 30 DAT), which had values lower than those found at 40 DAT (Table 1). The increased in photosynthetic area of plants in the third harvest may have contributed to the increase in sugars, and other metabolites present in the plants (MOU, 2009; OZGEN; SEKERCI, 2011). This increase in total soluble solids content may turn the lettuce more vulnerable to pests by providing easily available nutrients (CHABOSSOU, 1987).

The evaluation at 40 DAT presented also $\mathrm{L}^{*}$ values significantly smaller, smaller values for parameter $b^{*}$ (increase in blue) and higher values of parameter $a^{*}$ (increase in red), differing from the first two evaluation times, showing that the lettuce at this age became darker (Table 1). Similar results were found by Colleta (2009) during storage of Brassica oleracea L. cultivars (purple cabbage and kale), and Rinaldi (2005) during storage of cabbage, showing that these vegetables suffer darkening with senescence during storage, as occurred with the senescence of lettuce in the field in the present study. Color is one of the most attractive quality attributes to the consumer, however, it varies in lettuce harvested at different stages of development, which may be related to the chlorophyll degradation process at maturation, revealing other pigments or increasing their synthesis.

There were no significant differences for 
titratable acidity, expressed as citric acid, in all periods (Table 1). Organic acids tend to decrease with aging due to its use as substrate for respiration or their conversion into sugars, but when maintained under constant environmental conditions, breathing occurs at a stable rate, with no consumption of organic compounds in oxidative reactions for breathing (CHITARRA; CHITARRA, 2005). Organic acids play an important role in the perception of taste by modifying the taste of sugars such as sucrose, which is masked by the presence of citric acid (SCHIFFERSTEIN; FRITJERS, 1990; BONNANS; NOBLE, 1993).

The relationship between soluble solids and titratable acidity (SS/TA) has been used to evaluate the palatability, as an index indicating the balance between sugars and acidity (CHITARRA; CHITARRA, 2005), in which a high value for the ratio SS/TA provides a mild flavor, while a low value provides an acid flavor (MATTEDI et al., 2011). The results of SS/TA ratio were 43.50 (20 DAT), 45.45 (30 DAT) and 48.20 (40 DAT), thus, the taste of the lettuce became mild during ripening and less acid, which may have a better acceptance by the consumers, who prefer a lettuce with mild-sweet taste (MELLO et al., 2003).

The concentration of total carotenoids was significantly higher at 40 DAT compared to 20 and 30 DAT, which presented no significant differences (Table 1). The accumulation of pigments can also be confirmed by the low values of the color parameters $\mathrm{L}^{*}$ and $\mathrm{b}^{*}$ observed, showing that the lettuce leaves became darker after 40 DAT. The evolution of maturation cause chlorophyll degradation, making visible pre-existing pigments or synthesizing new pigments (ANDRADE JÚNIOR; ANDRADE 2012). Moreover, synthesis of pigments such as the carotenoids, is regulated by light (MOU, 2009), thus, the plants at $40 \mathrm{DAP}$, subjected to light for a longer period, probably accumulated a greater amount of these compounds. According to Rodriguez-Amaya; Kimura e Amaya-Farfan (2008), the concentration of total carotenoids in lettuce can increase three to four times with maturation.

Most researches on ripening of vegetables is based on color, total soluble solids and acidity evaluations (MOTTA et al., 2015), which suffer considerable changes during development. These basic attributes are essential in establishing the maturation stage, and important in sensory detection of product quality by consumers (CARVALHO et al., 2011; FERREIRA et al., 2012). Another important attribute for the analysis of lettuce quality are carotenoids, which are substances that provide several benefits to human health.

According to Silva e Vizzoto (1994) and Silva; Rebelo e Müller (1995), there is an excessive accumulation of latex in the reproductive phase (bolting), causing the lettuce leaves become bitter and rigid, hence unfit for commercialization.
However, the nutritional data, in addition to the sensory attributes, must be taken into consideration to determine the optimal time to harvest. The samples taken at the time of bolting (40 DAT), in the present work, had high concentrations of carotenoids and total soluble solids, low $\mathrm{pH}$ and darker plants, which can be favorable for appearance and increase consumer acceptance, showing that the consumption of lettuce from this development stage should be reconsidered.

\section{CONCLUSION}

Based on the results of this work, considering the high carotenoid concentrations and soluble solid contents found in the samples harvested at 40 DAT, during bolting, the harvest of lettuce plants can take place up to this stage. This practice would increase the harvest time by the producer, leaving the plant for a longer time in the field, and also increase the nutritional quality of plants for consumption.

Nowadays, people have become more aware about food, looking not only for food with pleasant sensory quality, but also for foods with good nutritional quality. Therefore, provide guidance to lettuce producers is necessary, since many of them care about harvesting products at times of better visual qualities, such as size and color, and few care about nutritional attributes, which are of great importance.

\section{ACKNOWLEDGMENTS}

The authors thank the Federal University of São João del Rei, FAPEMIG, CNPq and CVT-MG/ Guayi for financial support.

\section{REFERENCES}

ANDRADE JÚNIOR, M. C; ANDRADE, J. S. Physicochemical changes in cubiu fruits (Solanum sessiliflorum Dunal) at different ripening stages. Ciência e Tecnologia de Alimentos, Campinas, v. 32, n. 2, p. 250-254, 2012.

AOAC. ASSOCIATION OF OFFICIAL ANALYTICAL CHEMISTRY. Official methods of analysis of the Association of Official Analytical Chemistry. 19. ed. Gaithersburg: AOAC, 2012. $3000 \mathrm{p}$.

ARBOS, K. A. et al. Segurança alimentar de hortaliças orgânicas: aspectos sanitários e nutricionais. Ciência e Tecnologia de Alimentos, Campinas, v. 30, n. 1, p. 215-220, 2010. 
BECKER, C. et al. Cool-cultivated red leaf lettuce accumulates cyanidin-3-0-(6"-0-malonyl)-glucoside and caffeoylmalic acid. Food Chemistry, London, v. 146, n. 1, p. 404-411, 2014.

BENINNI, E. R. Y.; TAKAHASHI, H. W.; NEVES, C. S. V. J. Concentração e acúmulo de macronutrientes em alface cultivada em sistemas hidropônico e convencional. Semina: Ciências Agrárias, Londrina, v. 26, n. 3, p. 273-282, 2005.

BONNANS, S.; NOBLE, A. C. Effect of sweetener type and of sweetener and acid levels on temporal perception of sweetness, sourness and fruitiness. Chemical Senses, Oxford, v. 18, n. 3, p. 273-283, 1993.

CALDWELL, C. R.; BRITZ, S. J. Effect of supplemental ultraviolet radiation on the carotenoid and chlorophyll composition of green house-grown leaf lettuce (Lactuca sativa L.) cultivars. Journal of Food Composition and Analysis, San Diego, v. 19, n. 1, p. 637-644, 2006.

CARVALHO, P. G. B. et al. Hortaliças como alimentos funcionais. Horticultura Brasileira, Brasília, v. 24, n. 4, p. 397-404, 2006.

CARVALHO, A. V. et al. Qualidade pós-colheita de cultivares de bananeira do grupo 'maçã', na região de Belém - PA. Revista Brasileira de Fruticultura, Jaboticabal, v. 33, n. 4, p. 1095-1102, 2011.

CASTOLDI, R. et al. Crescimento, acúmulo de nutrientes e produtividade da cultura da couve-flor. Horticultura Brasileira, Brasília, v. 27, n. 4, p. 438446, 2009.

CHABOSSOU, F. Plantas doentes pelo uso de agrotóxicos: A teoria da trofobiose. 1. ed. Porto Alegre, RS: Editora Expressão Popular, 1987. 253 p.

CHITARRA, M. I. F.; CHITARRA, A. B. Póscolheita de frutos e hortaliças: fisiologia e manuseio. 2. ed. Lavras, MG: Editora UFLA, 2005. $783 \mathrm{p}$.

COLLETA, R. C. L. D. Respostas fisiológicas de cenoura, repolho roxo e couve minimamente processados isolados ou em combinação. 2009. 81 f. Dissertação (Mestrado em Ciências Agrárias: Área de Concentração em Fisiologia Vegetal) Universidade Federal de Viçosa, Viçosa, 2009.

FAO. Statistical Data base. 2012. Disponível em: $<$ http://faostat.fao.org/site/567/Desktop Default. aspx?PageID=567\#ancor $>$. Acesso em: 1 jul. 2014.

FAVARO-TRINDADE, C. S. et al. Efeito dos sistemas de cultivo orgânico, hidropônico e convencional na qualidade de alface lisa. Brazilian Journal of Food Technology, Campinas, v. 10, n. 2, p. 111-115, 2007.

FERREIRA, R. M. A. et al. Caracterização física e química de híbridos de tomate em diferentes estádios de maturação produzidos em Baraúna, Rio Grande do Norte. Revista Ceres, Viçosa, v. 59, n. 4, p. 506$511,2012$.

FILGUEIRA, F. A. R. Novo manual de olericultura: agrotecnologia moderna na produção e comercialização de hortaliças. 2. ed. Viçosa, MG: Editora UFV, 2003. 402 p.

GENT, M. P. N. Composition of hydroponic lettuce: effect of time of day, plant size, and season. Journal of the Science of Food and Agriculture, Chichester, v. 92, n. 3, p. 542-550, 2012.

GRANATO, D.; CALADO, V. M. A.; JARVIS, B. Observations on the use of statistical methods in food science and technology. Food Research International, Toronto, v. 55, n. 1, p. 137-149, 2014

GUEVARA-FIGUEROA, T. et al. Conditioning garlic "seed" cloves at low temperature modifies plant growth, sugar, fructan content, and sucrose sucrose fructosyl transferase (1-SST) expression. Scientia Horticulturae, Amsterdan, v. 189, n. 1, p. 150-158, 2015.

HAMADA, E.; TESTEZLAF, R. Desenvolvimento e produtividade da alface submetida a diferentes lâminas de água através da irrigação por gotejamento. Pesquisa Agropecuária Brasileira, Brasília, v. 30, n. 9, p. 1201-1209, 1995.

HASKELL, M. J. Provitamin A Carotenoids as a
Dietary Source of Vitamin A. In: TANUMIHARDJO, S. A. (Ed.). Carotenoids and Human Health, 1 ed., New York: Humana Press, 2013. 331 p.

HUANG, P. C. Effects of high-dietary fiber foods on blood and liver cholesterol and other lipids. Scientific Research Abstracts in Republic of China, Stanford, v. 1, n. 1, p. 98-99, 1980.

IBGE. Instituto Brasileiro de Geografia e Estatística. Pesquisa de orçamentos familiares 2008-2009: análise do consumo alimentar pessoal no Brasil. 1. ed. Rio de Janeiro, RJ: IBGE, 2011. 150 p.

INMET. Instituto Nacional de Metereologia. Dados meteorológicos para Sete Lagoas. 2014. Disponível em: $\quad<$ http://www.inmet.gov.br/portal/index.php? r=tempo/graficos $>$. Acesso em: 05 jun. 2014. 
LLORACH, R. et al. Characterization of polyphenols and antioxidant properties of five lettuce varieties and escarole. Food Chemistry, London, v. 108, n. 3, p. 1028-1038, 2008.

LUNA, M. C. et al. Optimizing water management to control respiration rate and reduce browning and microbial load of fresh-cut romaine lettuce. Postharvest Biology and Technology, Amsterdan, v. 80 , n. 1, p. 9-17, 2013.

LUZ, A. O. et al. Resistência ao pendoamento de genótipos de alface em ambientes de cultivo. Agrarian, Dourados, v. 2, n. 6, p. 71-82, 2009.

MAIANI, G. et al. Carotenoids: Actual knowledge on food sources, intakes, stability and bioavailability and their protective role in humans. Molecular Nutrition \& Food Research, Weinheim, v. 53, n. 2, p. 194-218, 2009.

MATTEDI, A. P. et al. Qualidade dos frutos de genótipos de tomateiro do Banco de Germoplasma de Hortaliças da Universidade Federal de Viçosa. Revista Ceres, Viçosa, v. 58, n. 4, p. 525-530, 2011.

MAUROMICALE, G.; IERNA, A.; MARCHESE, M. Chlorophyll fluorescence and chlorophyll content in field-grown potato as affected by nitrogen supply, genotype, and plant age. Photosynthetica, Praha, v. 44, n. 1, p. 76-82, 2006.

MELLO, J. C. et al. Efeito do cultivo orgânico e convencional sobre a vida-de-prateleira de alface americana (Lactuca sativa L.) minimamente processada. Ciência e Tecnolologia de Alimentos, Campinas, v. 23, n. 3, p. 418-426, 2003.

MOTTA, J. D. et al. Índice de cor e sua correlação com parâmetros físicos e físico-químicos de goiaba, manga e mamão. Comunicata Scientiae, Bom Jesus, v. 6 , n. 1, p. 74-82, 2015.

MOU, B. Nutrient content of lettuce and its improvement. Current Nutrition and Food Science, Sharjah, v. 5, n. 4, p. 242-248, 2009.

NICOLLE, C. et al. Health effect of vegetable-based diet: lettuce consumption improves cholesterol metabolism and antioxidant status in the rat. Clinical Nutrition, Luxembourg, v. 23, n. 4, p. 605-614, 2004a.

NICOLLE, C. et al. Characterization and variation of antioxidant micronutrients in lettuce (Lactuca sativa folium). Journal of the Science of Food and Agriculture, Chichester, v. 84, n. 15, p. 2061-2069, 2004b.

NIIZU, P. Y., RODRIGUEZ-AMAYA, D. B. New data on the carotenoid composition of raw salad vegetables. Journal of Food Composition and Analysis, San Diego, v. 18, n. 8, p. 739-749, 2005.

OZGEN, S.; SEKERCI, S. Effect of leaf position on the distribution of phyto-chemicals and antioxidant capacity among green and red lettuce cultivars. Spanish Journal of Agricultural Research, Madrid, v. 9, n. 3, p. 801-809, 2011.

PINTO, E. et al. Changes in macrominerals, trace elements and pigments content during lettuce (Lactuca sativa L.) growth: Influence of soil composition. Food Chemistry, London, v. 152, n. 1, p. 603-611, 2014.

PÔRTO, M. L. A. et al. Doses de nitrogênio no acúmulo de nitrato e na produção da alface em hidroponia. Horticultura Brasileira, Viçosa, v. 30, n. 3, p. 539-543, 2012.

RICARDO, A. S. et al. Telas de sombreamento no desempenho de cultivares de alface. Nucleus, Ituverava, v. 11, n. 2, p. 433-442, 2014.

RINALDI, M. M. Conservação do repolho minimamente processado em diferentes sistemas de embalagem. 2005. 110 f. Dissertação (Doutorado em Engenharia Agrícola) - Universidade de Campinas, Campinas, 2005.

ROCHA, D. S.; REED, E. Pigmentos naturais em alimentos e sua importância para a saúde. Estudos, Goiânia, v. 41, n. 1, p. 76-85, 2014.

RODRIGUEZ-AMAYA, D. B. A guide to carotenoid analysis in foods. 1. ed. Campinas, SP: UNICAMP, 2001. 71 p.

RODRIGUEZ-AMAYA, D. B.; KIMURA, M.; AMAYA-FARFAN, J. Fontes brasileiras de carotenóides: tabela brasileira de composição de carotenóides em alimento. 1. ed. Brasília, DF: MMA/SBF, 2008. 101 p.

SCHIFFERSTEIN H. N. J; FRITJERS J. E. R. Sensory integration in citric acid/sucrose mixtures. Chemical Senses, Oxford, v. 15, n. 1, p. 87-109, 1990.

SILVA, A. C. F.; VIZZOTTO, V. J. Avaliação de cultivares de alface no verão para o Litoral Catarinense. Agropecuária Catarinense, Florianópolis, v. 1, n. 1, p. 23-27, 1994.

SILVA, A. C. F.; REBELO, J. A.; MÜLlER, J. J. V. Produção de sementes de alface em pequena escala. Agropecuária Catarinense, Florianópolis, v. 8, n. 1, p. 41-44, 1995. 
YURI, J. E. et al. Comportamento de cultivares de alface tipo americana em Boa Esperança.

Horticultura Brasileira, Viçosa, v. 20, n. 2, p. 229232, 2002.

XIAO, Z. et al. Assessment of vitamin and carotenoid concentrations of emerging food products: edible microgreens. Journal of Agricultural and Food Chemistry, Washington, v. 60, n. 31, p. 7644-7651, 2012. 